\title{
Pemberdayaan Kelompok Rumah Pangan Lestari dalam Budidaya Tanaman Hidroponik
}

\author{
Pindo Tutuko ${ }^{1}$, Triyanna Widiyaningtyas ${ }^{2}$, Elta Sonalitha ${ }^{3}$, Bambang Nurdewanto ${ }^{4}$ \\ ${ }^{1}$ Program Studi Arsitektur, Fakultas Teknik Universitas Merdeka Malang \\ ${ }^{2}$ Fakultas Teknologi Informasi Universitas Negeri Malang \\ ${ }^{3,4}$ Fakultas Teknologi Informasi Universitas Merdeka Malang \\ e-mail : pindotutuko@unmer.ac.id
}

\begin{abstract}
Abstrak
Pertanian di perkotaan bukan hal yang tidak mungkin diadakan, pertanian dapat dilakukan di setiap rumah dan lingkungan sekitar rumah. Salah satu upaya menyeimbangkan kebutuhan pangan dan jumlah kebutuhan pangan di perkotaan adalah dengan dibentuknya Kelompok Rumah Pangan Lestari (KRPL). Studi ini dilakukan di 2 lokasi mitra yang terletak di 2 kelurahan di kota Malang.Metode yang dilakukan adalah dengan melakukan pelatihan tanam, pelatihan perawatan, dan pelatihan teknik pemanenan. Hasil menunjukkan bahwa dengan penanaman model hidroponik ini pada KRPL lebih bisa dimanfaatkan oleh warga dan membudidayakannya dengan lebih mudah dalam rangka memenuhi kebutuhan pangan keluarga.
\end{abstract}

Kata kunci: hidroponik; KRPL; urban farming.

\begin{abstract}
Urban agriculture is not impossible; agriculture can be done in every house and neighborhood. One effort to balance food demand and the amount of food demand in urban areas is the establishment of Sustainable Food House Group (KRPL). This study was conducted in 2 partner locations located in 2 urban villages in Malang. The methods used are planting training, maintenance training, and harvesting technique training. The results shows that with the planting of this hydroponic model on KRPL can be more utilized by the residents and cultivate it more easily in order to meet the needs of family food.
\end{abstract}

Keywords: Hydroponics; KRPL; Urban Farming

\section{PENDAHULUAN}

Permasalahan akan kebutuhan pangan dan perumahan merupakan hal yang tidak bisa dipisahkan. Upaya menyeimbangkan kebutuhan pangan dan kebutuhan perumahan bukanlah hal yang mudah. Kebutuhan perumahan lebih diutamakan karena memiliki nilai ekonomi yang lebih besar. Berkurangnya produksi pangan ini akan berakibat pada pemenuhan kebutuhan pangan masyarakat. Jumlah perumahan di perkotaan semakin meningkat seiring dengan bertambahnya jumlah penduduk. Semakin banyak lahan pertanian dan perkebunan yang dikonversi menjadi perumahan, akan mengurangi produksi pangan.

Akibat pertumbuhan suatu kota, maka ada permasalahan keterbatasan lahan untuk 
mengatasi permasalahan pangan di perkotaan., salah satunya melalui urban farming(Suparwoko and Taufani). Sejalan dengan hal ketahanan pangan di perkotaan, maka perlu adanya strategi dan klasifikasi bagi rumah-rumah yang terpengaruh oleh dampak dari perkembangan kota (N.Speybroeck et al.; Roy, Tony, and Paul). Permasalahan keterbatasan lahan di perkotaan menyisakan sedikit ruang untuk bercocok tanam, namun hal itu bukan menjadi penghalang untuk tetap melakukan tanam-menanam (Alviani). Penanaman Hidroponik adalah salah satu solusi yang efektif untuk penanaman di lingkungan sekitar rumah. Kebutuhan air pada hidroponik lebih sedikit dibandingkan pada budidaya tanaman dengan media tanah.

Pertanian di perkotaan adalah hal yang paling mungkin diadakan, karena penanaman dapat dilakukan di setiap rumah dan lingkungan sekitar rumah. Beberapa studi tentang Urban farming yang menggunakan hidroponik juga menyatakan dapat membantu iklim perkotaan menjadi lebih sejuk dan juga membantu penghuni perumahan di perkotaan dalam kebutuhan akan sayuran dan buah (Saha and Eckelman; Yi-Yu, Chien-Teh, and Yen-Chi). Jika dimulai dari lingkungan terkecil dalam masyarakat yaitu rumah, maka akan dapat memenuhi kebutuhan pangan minimal untuk rumah tersebut. Selain untuk pangan, pertanian di perkotaan mampu membantu penghijauan kota. Selain untuk penghijauan kota maka tujuan dari kegiatan ini adalah menjawab kebutuhan pangan perkotaan yaitu alternatif swasembada pangan khususnya sayur dan buah.

Dikaitkan dengan model urban farming, maka terdapat 3 pertimbangan, yaitu: berpendapatan rendah, spesialisasi, dan diversifikasi dalam mengembangkan model penanaman di perkotaan di negara sedang berkembang (Pölling, Marcus, and Wolf), hal ini sesuai dengan kondisi di Indonesia. Salah satu pelaku pengembangan ekonomi sebuah rumah adalah ibu rumah tangga, hal ini semakin nampak jelas perannya dengan kegiatankegiatan yang ada di kelompok Pemberdayaan dan Kesejahteraan Keluarga (PKK) Kegiatankegiatan dalam PKK bervariasi pada setiap lingkungan masyarakat, tergantung sejauh mana kreatifitas anggotanya. Semakin membuka diri terhadap kreasi dan partisipasi anggota, semakin tumbuh dan berkembang organisasi PKK. Saat ini banyak kelompok PKK yang melakukan usaha kreatif di area Rukun Tetangga (RT) maupun Rukun Warga (RW) yang tujuannya untuk mengisi waktu, menambah ketrampilan dan pengetahuan, dengan tanpa meninggalkan kewajibannya mengatur rumah tangga. Usaha kreatif yang dilakukan salah-satunya adalah dibentuknya Kelompok Rumah Pangan Lestari (KRPL) yang diharapkan mampu meningkatkan kesejahteraan masing-masing anggota dengan cara swasembada pangan.

PKK RT 08 RW 02 Kelurahan Lowokwaru Kota Malang terdiri dari 8 Pengurus dan 38 Anggota yang terdiri dari Ibu-Ibu di lingkungan RT 8. Kepengurusan PKK terdiri dari Ketua PKK, sekretaris PKK, bendahara, dan seksi-seksi yang secara rutin mengadakan pertemuan PKK, seperti pada gambar 1. Ibu-ibu di lingkungan ini mayoritas mempunyai kegemaran yang sama terhadap pemeliharaan tanaman dan pemanfaatan lahan di sekitar rumahnya.

Program kerja PKK terdiri dari 10 program pokok yang salah satu nya adalah pangan. Tugas PKK adalah memberikan motivasi dan inspirasi kepada masyarakat terutama perempuan dalam mewujudkan penghijauan dan pelestarian lingkungan dengan mengoptimalkan pemanfaatan pekarangan yang semula hanya ditanami berbagai bunga 
dan tanaman hias sebagai penunjang estetika. Penanaman lain berupa pohon buah, sayursayur organik dan tanaman obat keluarga (Toga). Pekarangan bukan hanya menciptakan keindahan dan kesejukan saja, tetapi lebih dari itu dapat meningkatkan kesejahteraan keluarga melalui penanaman tanaman sayur sayuran, buah buahan, tanaman obat obatan, serta tanaman hias.
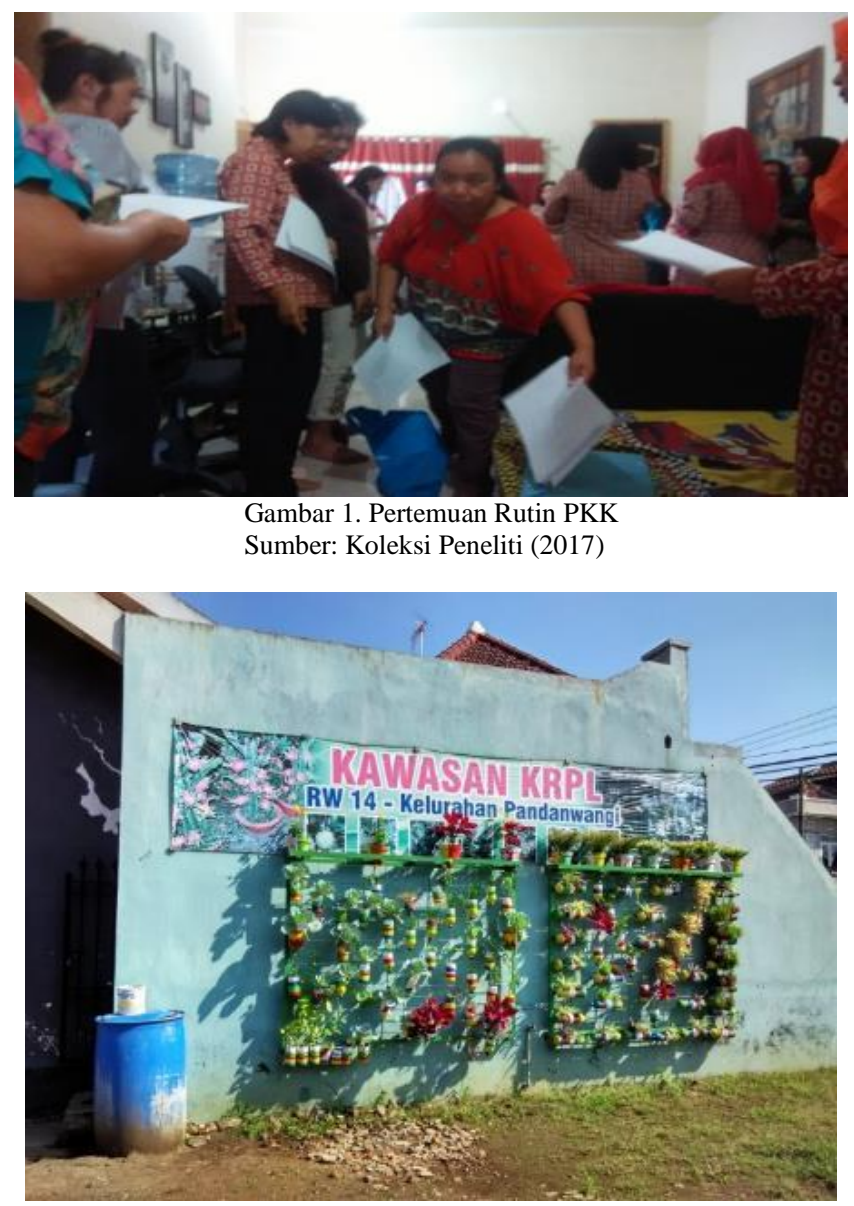

Gambar 2. Tanaman Organik KRPL

Sumber: Koleksi Peneliti (2017)

Kelompok KRPL berikutnya adalah Posdaya ASLI yang berlokasi di kelurahan Pandanwangi Kota Malang yang dibentuk dengan harapan mampu menjadi kelompok yang menggiatkan masyarakat untuk swasembada pangan. Posdaya Asli didirikan sebagai forum silaturahmi, komunikasi, advokasi dan wadah penguatan fungsi-fungsi keluarga secara terpadu. Dalam hal tertentu, bisa juga menjadi wadah pelayanan keluarga secara terpadu yaitu pelayanan pengembangan keluarga secara berkelanjutan dalam berbagai bidang, utamanya kesehatan, pendidikan dan ekonomi, lingkungan, agama, dan budaya. Upaya dalam segi pangan selama ini adalah penanaman tanaman organik dan pemeliharaan hewan-hewan seperti unggas ayam, bebek dan angsa, seperti pada Gambar 2.

Salah satu alternatif swasembada pangan yang sesuai adalah sistem penanaman Hidroponik. Penanaman tanaman Hidroponik mempunyai kelebihan antara lain : penggunaan lahan lebih efisien, tanaman berproduksi tanpa menggunakan tanah, kuantitas dan kualitas 
produksi lebih tinggi dan lebih bersih, penggunaan pupuk dan air lebih efisien, pengendalian hama dan penyakit lebih mudah. Penggunaan media air ini juga bisa dikembangkan dengan menggunakan konduksi listrik untuk memperkaya nutrisi bagi hidroponik (Liopa-Tsakalidi, Barouchas, and G. Salahas). Oleh sebab itu Sistem Penanaman Hidroponik dapat dijadikan pilihan yang tepat bagi penghijauan dan produksi pangan di lingkungan rumah yang dapat dibudidayakan sampai mampu mendapatkan penghasilan tambahan bagi pembudidayanya.

Sumber inspirasi dari kegiatan ini adalah bahwa saat ini banyak kelompok PKK yang melakukan usaha kreatif di area Rukun Tetangga (RT) maupun Rukun Warga (RW) yang tujuannya untuk mengisi waktu, menambah ketrampilan dan pengetahuan, tanpa meninggalkan kewajibannya mengatur rumah tangga. Usaha kreatif yang dilakukan juga diharapkan dapat menghasilkan pendapatan dengan jumlah yang mampu meningkatkan kesejahteraan masing-masing anggota. Hal ini menjadi tantangan bahwa peran wanita sangat dibutuhkan dalam mencukupi kebutuhan pangan keluarga dengan memanfaatkan lahan yang ada pada daerah perumahan. Seperti kita ketahui bersama bahwa lahan di perumahan yang ada di perkotaan sebagian besar memiliki halaman yang terbatas, sehingga hal ini diharapkan kana menjadi solusi bagi peningkatan usaha atau ekonomi rumah tangga.

\section{METODE KEGIATAN}

Metode yang dipakai adalah partipasi masyarakat berupa kegiatan kegiatan yang ditujukan untuk mendukung aktifitas kelompok PKK RT 08 RW 03 di kelurahan Tunjungsekar dan POSDAYA ASLI di kelurahan Pandanwangi di kota Malang, khususnya di bidang pangan. Hal ini dengan cara menumbuhkan semangat berswasembada pangan dengan memberikan wawasan melalui pelatihan dan pendampingan. Adapun pelaksanaan yang dilakukan adalah

1. Melakukan pelatihan penanaman tanaman Hidroponik.

2. Melakukan pelatihan perawatan tanaman Hidroponik.

3. Melakukan pelatihan teknik Pemanenan.

Pelatihan-pelatihan ini bertujuan agar

KRPL sebagai pengelola sumber daya manusia mampu menggerakkan anggotanya untuk menyerap materi keterampilan hidroponik yang diajarkan. Teknik dasar adalah teknik penanaman. Teknik ini diawali dengan persiapan lahan dan bahan yang akan digunakan. Penjelasan tentang teknik pemilihan bibit dan perlakuan terhadap bibit. Selanjutnya dilakukan kegiatan tentang penjelasan tentang penanaman.

\section{KARYA UTAMA}

Karya utama yang dihasilkan adalah buku panduan metode tanam hidroponik mulai dari persiapan, penanaman, perawatan, dan pemanenan. Hal ini akan memberikan pemahaman baru sehingga mereka dapat memproduksi secara mandiri buah dan sayur yang dihasilkan dari sistem tanam hidroponik. Selanjutnya para mitra akan diberi panduan untuk menjalankan aplikasi penjualan berbasis Web Commerse, dimana sistem ini menggunakan bahasa pemrograman PHP dan MySQL sebagai basis data dan akan menghasilkan suatu bentuk layanan toko online yang disediakan oleh administrator untuk menerima pesanan dan mengirim konfirmasi pembayaran maupun konfirmasi pengiriman. Alasan menggunakan Web Commerse sebagai media transaksi adalah untuk mempercepat pendistribusian hasil panen. Setiap pesanan yang masuk akan ditindaklanjuti melalui email, 
SMS atau Private Chat. Kemudian pembeli melakukan konfirmasi pembelian dengan cara mengirimkan foto bukti transfer. Hasil panen akan dikirim sesuai pesanan.

\section{ULASAN KARYA}

\section{Persiapan Peralatan dan Perlengkapan.}

Persiapan diawali dengan koordinasi KRPL Kelurahan Pandanwangi kecamatan Blimbing dan PKK RT 08 RW 02 Tunjungsekar Kota Malang untuk membahas persiapan pelaksanaan program Ipteks bagi Masyarakat kerjasama Universitas Merdeka Malang dengan Ristekdikti.

Persiapan lainnya meliputi tempat/area hidroponik, Pipa dengan Lubang Pot, Pot, Pompa air, Alat pengukur kesehatan nutrisi, Modul-modul media Rockwool, Bibit, dan Nutrisi. Dalam persiapan ini, Universitas Merdeka Malang bekerjasama dengan kelompok pembudidaya hidroponik rumahsayurku. Kelompok ini merupakan konsultan dan pembagi pengalaman di bidang hidroponik.

Beberapa media yang digunakan, adalah sebagai berikut :

1. Pipa-pipa PVC dirangkai membentuk model A dan setengah A sehingga tanaman bisa mengakses sinar matahari, seperti pada gambar 3 .

2. Alat ukur nutrisi digunakan untuk menjaga kesehatan kadar nutrisi dalam air agar didapat hasil yang optimal, seperti pada Gambar 4.

3. Nutrisi sebaiknya menggunakan nutrisi $A B$ mix dengan kadar yang terukur dan sesuai kebutuhan tanaman.

4. Air yang digunakan juga harus dalam kategori air bersih yaitu kurang dari 200 ppm. pH air antara 5,5 sampai 6,5, dan harus berada pada suhu air 18 sampai 26 derajat celsius.

5. Udara yang dibutuhkan adalah udara dengan sirkulasi sehat dan bebas polusi. Udara sebaiknya memenuhi kandungan karbon, oksigen dan hidrogen yang cukup. Selain udara juga diperlukan pencahayaan sinar matahari pagi dan sore.

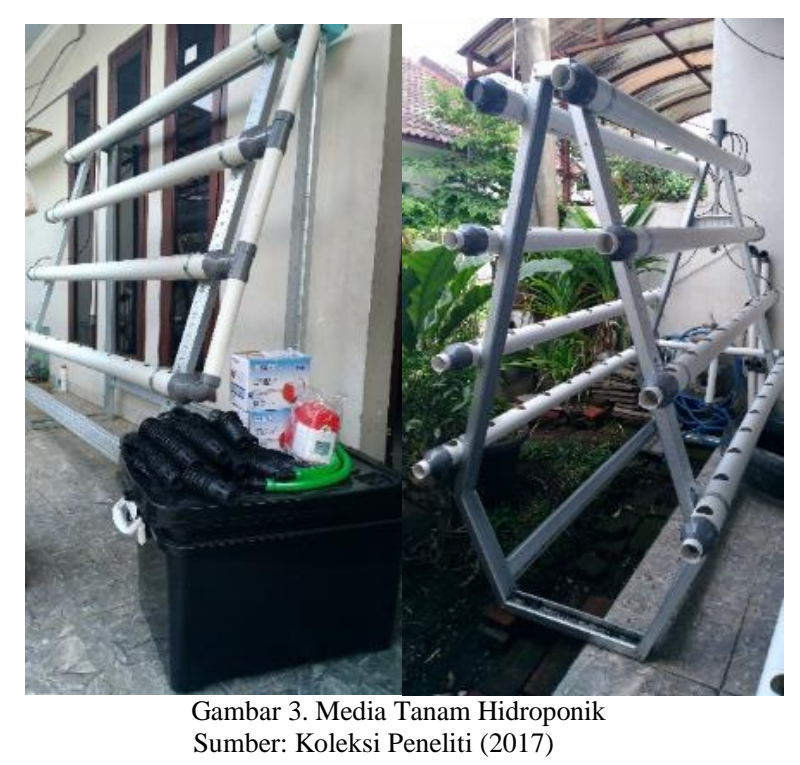




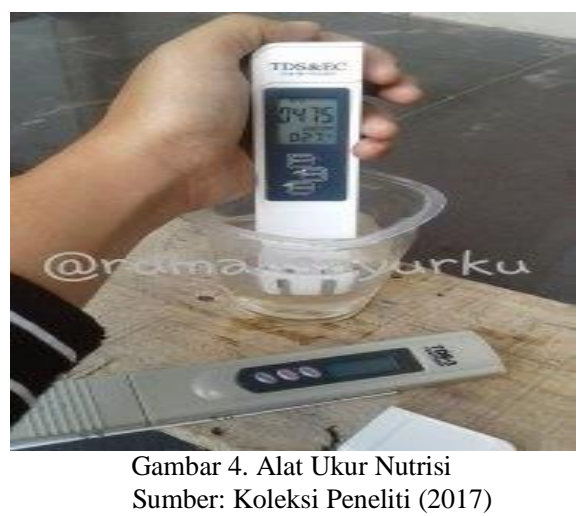

\section{Pelatihan Dasar Hidroponik}

Pelatihan ini dilaksanakan di RW 14 Kelurahan Pandanwangi pada tanggal 16 Juni 2017 dengan 36 orang peserta pelatihan. Pelatihan pertama adalah tentang pengertian hidroponik, penjelasan peralatan, cara semai, cara tanam secara sekilas untuk memberi gambaran tentang penanaman hidroponik.

Pelatihan berikutnya adalah teknik semai hidroponik. Pelatihan ini menjelaskan tentang perbedaan semai masing-masing biji dari jenis sayuran, beda sayur beda pula teknik penanaman, jarak, jumlah dan kedalaman tanam. Pelatihan ini langsung mempraktekkan semai untuk berbagai jenis bibit. Semai pertama antara lain tanaman sayur kangkung, bayam, selada kriting hijau, selada kriting merah, pokchoi dan caisim dilakukan pada tanggal 8 Juni 2017, dan pindah tanam dilakukan tanggal 20 Juni 2017.

Teknik semai menggunakan Rockwool mempunyai beberapa keuntungan antara lain mampu menahan air, sesuai dengan sistem Deep Flow Technique (DFT), NFT), Wick dan
Rakit Apung (Floating Raft). Media Rockwool lebih fleksibel meski banyak media lain yang bisa digunakan seperti Sekam, Cocopeat, Hidroton, Spons dan Zeolite. Rockwool ini dipotong dengan ukuran $2 \mathrm{~cm}$ x 2,5 cm x 2,5 $\mathrm{cm}$. Beberapa langkah semai antara lain :

a. Rockwool yang sudah terpotong diletakkan pada nampan/keranjang, dibasahi dengan air sehat dan ditiriskan.

b. Melubangi Rockwool yang basah dengan tusuk gigi sebesar benih yang mau ditanam.

c. Memasukkan benih sedalam $2 \mathrm{~mm}$ (standart), atau kedalaman sesuai dengan jenis bibit.

d. Kelembaban rockwool harus tetap terjaga.

e. Setelah berkecambah, semaian harus dijemur di tempat full matahari.

f. Setelah berdaun 4 atau sekitar 10 sampai 14 hari bibit siap dipindah tanam ke hidroponik system, seperti pada Gambar 5. Lama setiap jenis tanaman bisa berbedabeda. 


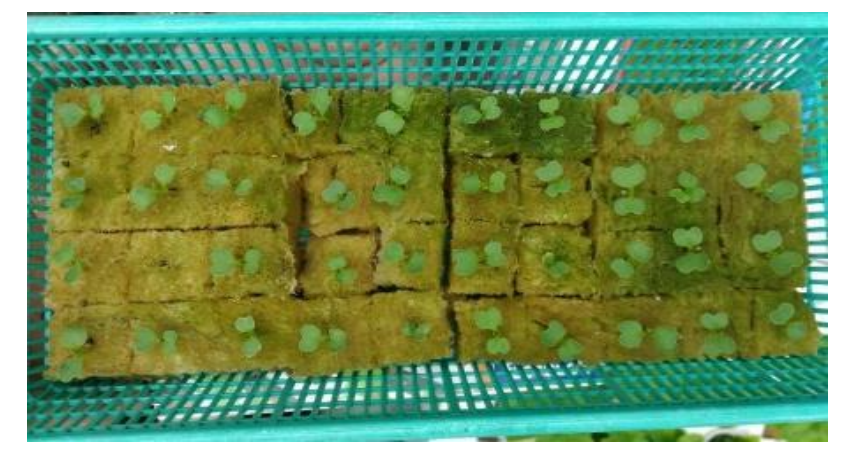

Gambar 5. Penyemaian benih pada Rockwool Sumber: Koleksi Peneliti (2017)

\section{Pelatihan Tanam}

Penanaman hidroponik mempunyai beberapa metode/cara, antara lain Sumbu (Wick), Rakit Apung (Floating Raft), Deep Flow Technique (DFT), Nutrient Film Tecnique (NFT), Fertigasi, Dutch Bucket (DB). Beberapa alat yang digunakan dalam teknik sumbu antara lain Netpot untuk menopang tanaman, Kain Flanel untuk sumbu, TDS/EC meter untuk mengukur kepekatan atau kadar nutrisi dalam satuan ppm atau ec, $\mathrm{pH}$ meter sebagai alat pengukur $\mathrm{pH}$ atau derajat asam pada laturan nutrisi.

Peralatan lainnya antara lain selang dan nepel, alat bantu menyalurkan nutrisi sehingga terbagi secara merata, dan pompa air untuk mengalirkan nutrisi dari bak atau tandon ke sistem hidroponik. Pelatihan dalam program ipteks ini akan diberikan 2 cara penanaman saja yaitu cara tanam Sumbu dan DFT.

\section{Cara Tanam Sumbu (Wick)}

Cara TanamSumbu ini adalah teknik yang mudah dilakukan untuk pemula. Cara tanam ini bersifat pasif yaitu tidak membutuhkan sirkulasi nutrisi. Sumbu akan menyuplai nutrisi ke akar untuk diteruskan ke seluruh tubuh tanaman. Nutrisi akan didistribusi ke akar dan tubuh tanaman menggunakan daya kapilaritas air melalui sumbu, seperti pada Gambar 6.

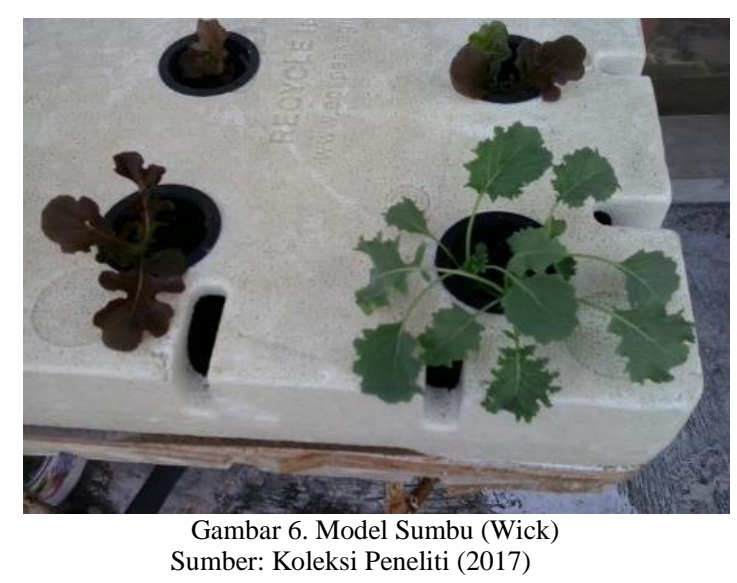




\section{Cara Tanam Deep Flow Technique (DFT)}

Cara tanam ini merupakan instalasi dengan pipa berlubang dengan jarak tanam disesuaikan dengan jenis tanaman, dan disusun sejajar, seperti pada Gambar 7. Nutrisi akan mengalir di akar dengan kondisi tergenang sehingga sebagian akar terendam lautan nutrisi. Teknik DFT ini diterapkan di kedua kelompok mitra, dengan menggunakan instalasi pipa, besi galvalum, bak tandon, dan pompa, seperti pada Gambar 8 .

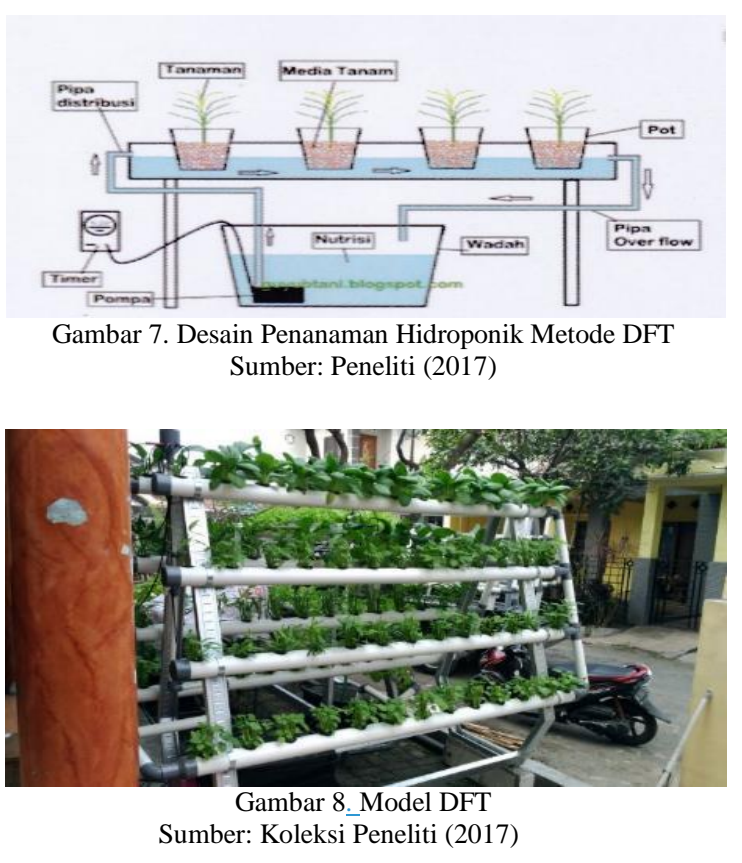

\section{Perawatan dan Nutrisi}

Penanaman hidroponik

\begin{abstract}
tidak
\end{abstract} memerlukan perawatan yang terlalu rumit, cukup menjaga kadar keasaman air dan kesesuaian nutrisi. Selain itu menjaga area penanaman hidroponik dari hama. Nutrisi yang diperlukan tanaman disesuaikan dengan kebutuhan tanaman atau jenis tanaman. Nutrisi yang terjaga akan menghasilkan tanaman yang sehat dan bergizi.

\begin{abstract}
Hasil panen KRPL Kelurahan Pandanwangi merupakan tanaman sayursayuran yang dapat dikonsumsi sehari-hari, seperti pada Gambar 9. Sayur hasil hidroponik ini dimanfaatkan kelompok KRPL untuk kesejahteraan amggotanya dengan cara menjual dengan harga lebih murah dari harga pasar, dan hasil penjualannya dimasukkan ke dalam kas KRPL untuk digunakan untuk pembelian bibit dan nutrisi kembali.
\end{abstract}

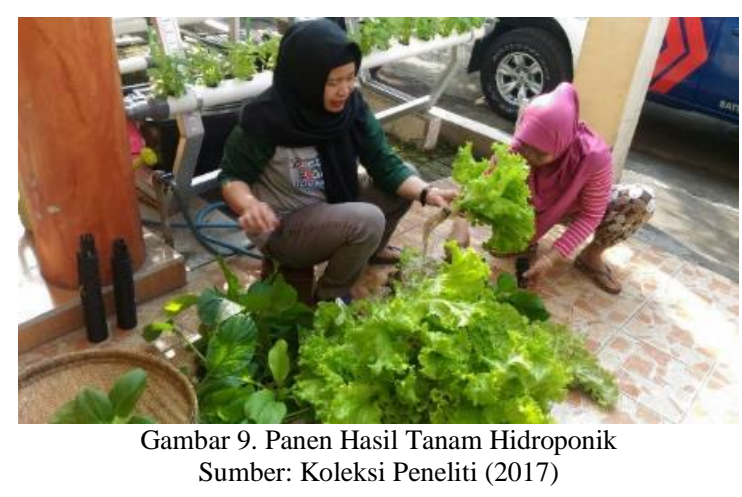


Sedangkan secara kuantitatif dapat dilihat pada Tabel 1, menunjukkan terdapat penambahan jenis tanaman sayuran yang semula 7 jenis tanaman menjadi 12 jenis tanaman.

Tabel 1. Jenis tanaman sayuran yang ditanam

\begin{tabular}{ll}
\hline Sebelum & Sesudah \\
\hline 1. Seledri & 1. Seledri \\
2. Selada & 2. Terong \\
3. Bayam & 3. Selada \\
4. Tomat & 4. Okra \\
5. Kangkung & 5. Pakchoy \\
6. Sawi & 6. Bayam \\
7. Cabe & 7. Tomat \\
& 8. Kangkung \\
& 9. Mint \\
& 10. Sawi \\
& 11. Cabe \\
& 12. Kailan \\
\hline
\end{tabular}

\section{KESIMPULAN}

Setelah pelatihan Metode Penanaman Hidroponik, Kelompok Rumah Pangan Lestari dapat menghasilkan produksi pangan (buah dan sayuran) di lingkungan rumah. Selain swasembada pangan juga untuk penghijauan, dan mendapatkan penghasilan tambahan. Pengembangan selanjutnya adalah dapat menganalisa kebutuhan bahan pangan (buah dan sayuran) di pasaran, dan hasil panen dikemas secara layak sehingga dapat dijual ke pelaku bisnis hotel dan restoran. Pemasaran dapat menggunakan web commerse sehingga pangsa pasar lebih luas. Luaran yang dihasilkan Buku "Panduan Praktis berHidroponik" yang akan mempermudah pehamaman kepada ibu-ibu di lokasi mitra terhadap proses penanaman Hidroponik sampai dengan panen. Secara kuantitatif jumlah variasi produk tanaman sayuran yang bisa dihasilkan dan dipasarkan lebih banyak daripada sebelumnya. Selanjutnya untuk menjaga keberlanjutan usaha ini, maka diperlukan usaha pengembangan pemasaran, yaitu dikembangkan melalui melalui toko online (https://lppm-unmer.net/productcategory/hidroponik/).

\section{PENGHARGAAN}

Terima kasih kami sampaikan kepada Kemenristek Dikti atas dukungan program Ipteks Bagi Masyarakat (IbM) tahun 2017, kelompok PKK RT08 RW03 Kelurahan Tunjung Sekar Kota Malang, Kelompok Posdaya ASLI Kelurahan Pandanwangi Kota Malang, HIMA, rumahsayurku, dan pihakpihak yang membantu berjalannya kegiatan ini.

\section{VII.DAFTAR PUSTAKA}

Alviani, Puput. Bertanam Hidroponik Untuk Pemula: Cara Bertanam Cerdas Di Lahan Terbatas. 1st ed. Depok, jawa Barat: Bibit Publisher, (2015). Print.

Liopa-Tsakalidi, A., P. Barouchas, and G. Salahas. "Response of Zucchini to the Electrical Conductivity of the Nutrient Solution in Hydroponic Cultivation." Agriculture and Agricultural Science Procedia 4 (2015): 459-462. Web. 19 Sept. 2017.

N.Speybroeck et al. "Classification Trees versus Multinomial Models in the Analysis of Urban Farming Systems in Central Africa." Agricultural Systems 80.2 (2004): 133-149. Web. 18 Sept. 2017. 
Pölling, Bernd, Mergenthaler Marcus, and Lorleberg Wolf. "Professional Urban Agriculture and Its Characteristic Business Models in Metropolis Ruhr, Germany." Land Use Policy 58 (2016): 366-379. Web. 18 Sept. 2017.

Roy, Maconachie, Binns Tony, and Tengbe Paul. "Urban Farming Associations, Youth and Food Security in Post-War Freetown, Sierra Leone." Cities 29.3 (2012): 192-200. Web. 18 Sept. 2017.

Saha, Mithun, and Matthew J. Eckelman. "Growing Fresh Fruits and Vegetables in an Urban Landscape: A Geospatial Assessment of Ground Level and Rooftop Urban Agriculture Potential in Boston,
USA." Landscape and Urban Planning 165 (2017): 130-141. Web. 19 Sept. 2017. Suparwoko, and Betri Taufani. "Urban Farming Construction Model on the Vertical Building Envelope to Support the Green Buildings Development in Sleman, Indonesia." Procedia Engineering 171 (2017): 258-264. Web. 18 Sept. 2017.

Yi-Yu, Huang, Chen Chien-Teh, and Tsai YenChi. "Reduction of Temperatures and Temperature Fluctuations by Hydroponic Green Roofs in a Subtropical Urban Climate." Energy and Buildings 129 (2016): 174-185. Web. 19 Sept. 2017. 